\title{
Engaging foreign language students via hybrid learning
}

\author{
Envolviendo a los estudiantes de una lengua extranjera a través del aprendizaje híbrido \\ Brita Banitz $^{a}$, Patricia Lanners-Kaminski ${ }^{b}$
}

\begin{abstract}
:
Our article aims to encourage foreign language teachers at higher education institutions in Mexico to implement hybrid learning in their classrooms in order to increase learner engagement with the foreign language and to provide more opportunities to practice the target language outside the classroom. We begin by defining hybrid or blended learning and some of its advantages, distinguishing this mixed method from the flipped classroom. We then discuss and exemplify in greater detail which tools we have chosen to support the online component of our classes and how we have implemented them. We conclude our article with a brief discussion of three concrete challenges we faced during the implementation process and how we resolved them reaching our conclusion that the implementation of hybrid learning needs to be well planned if it is to support the language learning process of our students.
\end{abstract}

\section{Keywords:}

Computer assisted language learning, hybrid learning, language learning, learning applications, technology-enhanced language learning

\section{Resumen:}

Nuestro artículo pretende animar a los profesores de lengua extranjera en instituciones de educación superior en México a implementar el aprendizaje híbrido en sus aulas con el fin de envolver a los aprendices en la lengua extranjera y de ofrecerles más oportunidades para la práctica del idioma meta fuera del aula. Comenzamos con la definición del aprendizaje híbrido o mixto distinguiéndolo de la aula volteada. A continuación, discutimos y ejemplificamos con más detalle qué herramientas hemos elegido para apoyar al componente en línea y cómo las hemos implementado. Concluimos nuestro artículo con una breve discusión de tres desafíos concretos que enfrentamos durante el proceso de implementación y cómo los hemos resueltos, llegando así a la conclusión de que la implementación del aprendizaje híbrido debe ser bien planificada si se quiere apoyar al proceso de aprendizaje de idiomas de nuestros estudiantes.

\section{Palabras clave:}

Aprendizaje de de lenguas apoyado por computadoras, aprendizaje híbrido, aprendizaje de lenguas, aplicaciones para el aprendizaje, aprendizaje de lenguas apoyado por la tecnología

\section{INTRODUCTION}

As is well-known, students need approximately 700 to 1320 hours of instruction to reach advanced-level fluency (i.e., C1 according to the CEFR) in a foreign language (Blake, 2008). Knight (2018) suggests between 200 and 400 hours of language instruction are needed, to reach the next level in the Common European Framework. However, the reality at the private university in central Mexico in which we offer foreign language courses for undergraduate students as part of our curricular requirements is quite different. Our students have to take three foreign language courses, one per semester. Each course consists of 96 hours of instruction per semester and there are between 35 and 40 students in our (beginner) courses. Therefore, not only do students enrolled in the first level of a foreign language compete with 30 or more other students for the teacher's attention, they will also have to achieve a predetermined level of language proficiency in a total of 288 hours. Because we are teaching foreign languages in Mexico, an additional challenge is that upon leaving the classroom, students

Corresponding author, Universidad de las Américas Puebla, México, https://orcid.org/0000-0002-7254-0626, Email: brita.banitz@udlap.mx

${ }^{b}$ Universidad de las Américas Puebla, México, https://orcid.org/0000-0001-7393-6940, Email: patricia.lanners@udlap.mx 
automatically fall back into their native language which makes it even more difficult to keep learners involved with the foreign language outside the classroom. As a consequence, learners do not advance as fast as they, their teachers, and our Institution wish. We therefore implemented hybrid learning as a proposed solution to the aforementioned challenges. In what follows, we will first define hybrid learning in order to clarify what it is and what it is not. Next, we will share some examples of how we have implemented hybrid learning into our foreign language classrooms. Third, we will briefly discuss some of the challenges we have encountered and how we resolved them which leads us to our conclusions. By sharing our experiences, we aim to encourage fellow foreign language teachers in similar teaching contexts to consider, and if possible implement, hybrid learning in their own institutions to support the students in their foreign language learning process.

\section{THEORETICAL BACKGROUND}

Hybrid or blended learning, defined as «the thoughtful integration of face-to-face and online instruction» (Halverson \& Graham, 2019, p. 2), combines face-to-face, in-class instruction with a substantial amount of instruction delivered online, commonly between $30 \%$ to $79 \%$ (Park, Martin, \& Lambert, 2019). According to Park et. al (2019), this mixed delivery method

1. allow[s] students to take the benefits from both approaches $[\ldots]$,

2. help[s] students learn better [...], and

3. increase[s] access for more students. (p. 12)

Another important advantage of hybrid or blended learning over fully online instruction is that students «may be better guided toward effective learning [thanks to the in-class component], instead of being pushed to overcome the difficulties on their own» (Park, et. al, 2019, p. 12), as is so often the case with online learning on courses where there is insufficient support for learners, resulting in high drop-out rates.

Since all of the foreign language courses at our university have traditionally been face-to-face, with a very limited amount of time available for practicing the foreign language (three hours per week attending class and, in theory, three hours per week doing unguided homework), we opted for a 50/50 scenario in which new content is introduced, explained, and demonstrated in class $(50 \%$ of the course activities and final course grade for four hours per week) and practiced extensively online (the remaining $50 \%$ with a minimum of another four hours of guided exercises per week). The online component also includes additional material students can freely access, such as further explanations of important grammatical points or cultural information, as well as practice quizzes which prepare students for the exams. Our purpose in doing so is to increase learner engagement, defined by Halverson and Graham (2019) as "the involvement of the student's cognitive and emotional energy to accomplish a learning task» (p. 145), since it has been shown to increase «academic achievement, persistence, satisfaction, and [a] sense of community» (Halverson \& Graham, 2019, p. 145). We have found that students who come to class and work with the online component on a regular basis have better chances of successfully completing the course whereas students who either fail to attend class or miss the online activities have a higher probability of failing the course. By deciding to give both the in-class and online activities an equal weight, we are suggesting to our students that both components of the course are of equal importance to their learning process. As far as our decisions regarding which topics and types of activities to include in the online component are concerned, these were based on years of student feedback on teacher evaluation forms as well as student comments during mentoring sessions in our university's language learning center.

We would like to point out, however, that the hybrid or blended learning environment must not be confused with the flipped classroom, another method that is recently being implemented in many educational environments. Even though the flipped classroom (sometimes also referred to as reverse or inverse classroom) is another mixed method of instruction, «the essence of the flipped classroom is moving the 'delivery' of material outside of formal class time (by extensive notes, video-recorded lectures and other appropriate means) and using formal class time for students to undertake collaborative and interactive activities relevant to that material» (Wang, Huang, Schunn, Zou, \& Ai, 2019, p. 712). In our set-up, however, new content is delivered in class and further practiced online since all of our classes are registered at the Mexican Secretary of Public Education, the maximum education authority at the national level, as on-site only. This is why the implementation of a flipped classroom approach is not possible for language classes at our Institution. In the following section, we will explain in greater detail how we have implemented the online component in our hybrid learning environment.

\section{OUR IMPLEMENTATION OF HYBRID LEARNING}

To support additional out-of-class learning, we integrated various online applications. Some applications serve as a tool for engaging students in the target language beyond the classroom and are not part of the students' grade while others offer online additional practice and assessment in certain language skills which also represent an important part of the students' course grade. Figure 1 below shows the division into the three different kinds of activities we have designed for our foreign language courses. 


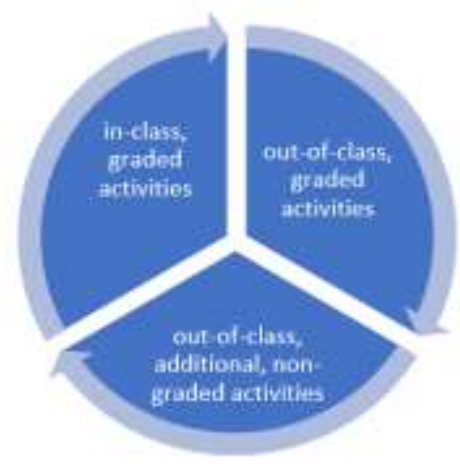

Figure 1: The division of in-class and out-of-class graded and non-graded activities

For additional practice as well as the assessment of the students' listening, speaking, and reading skills, we use the learning management system Blackboard, the only one available at our university, and the social learning video platform Flipgrid. Based on the results of writing done online and without the teacher's assistance in previous courses, however, we have found that practicing the writing skills is more effective if done directly in the classroom under the supervision of the teacher who is also available for questions as students are working on different writing tasks.

To engage our learners in additional out-of-class activities, we also utilize Instagram, Facebook, YouTube, Pinterest, Quizlet, and Duolingo Classroom. How we have implemented these tools in our foreign language classroom will be exemplified further below.

The different in-class and out-of-class activities are graded based on the scheme presented in Table 1 below. As can be seen in the table, each unit is divided into graded in-class and graded out-of-class activities (the example provided is from our German course, the only language for which the textbook we are currently using does not already include an online graded component. The percentages were determined based on weight of the activity and amount of time investment needed by the students).

\begin{tabular}{|l|l|}
\hline $\begin{array}{l}\text { In-class activities = 50\% } \\
\text { of each unit grade }\end{array}$ & $\begin{array}{l}\text { Out-of-class activities } \\
\text { (Blackboard and Flipgrid) }= \\
\text { 50\% of each unit grade }\end{array}$ \\
\hline $\begin{array}{l}\text { Worksheets: 50\% of } \\
\text { in-class grade } \\
\text { (delivered } \\
\text { not delivered =0) }\end{array}$ & $\begin{array}{l}\text { Exercises Blackboard: 40\% of } \\
\text { out-of-class grade }\end{array}$ \\
\hline $\begin{array}{l}\text { Writing practice: 40\% of } \\
\text { in-class grade }\end{array}$ & $\begin{array}{l}\text { Workbook: 40\% of out-of-class } \\
\text { grade }\end{array}$ \\
\hline $\begin{array}{l}\text { Attendance: 10\% of in- } \\
\text { class grade }\end{array}$ & Quiz: 20\% of out-of-class grade \\
\hline
\end{tabular}

Table 1: Grading rubric for each unit divided into in-class and out-of-class activities
For the in-class activities, we provide our students with additional handouts which are worth $50 \%$ of the in-class activities grade. Students who are present on the day a worksheet is being used, turn in that worksheet at the end of the class and will receive an automatic 10 for that activity. Students who are absent and who are therefore not completing the worksheet activity, will receive a 0 for that activity on the day they are absent. At the end of the unit, the average of all worksheet grades will be tallied and counted as $50 \%$ of the inclass grade. The writing practice consists of one writing prompt at the end of each unit which students have to answer in class. The text students produce on that day will be graded. Students who are absent on the day of the writing activity will receive a 0 for that activity. Since this activity is worth $40 \%$ of the in-class grade and encourages students to apply the structures they learned while working on the particular unit, we have found that it is an effective way to foster student attendance, which amounts to $10 \%$ of the in-class grade. Attendance is recorded every day and the attendance grade is calculated based on the number of days attended per unit.

In addition, students have to complete a number of out-of-class activities on Blackboard. Here we are only concerned that students do the activities and score at least half of the possible points in order to be assigned a 10 for the out-of-class activities for a particular unit. Moreover, students have to answer all of the exercises in the workbook that accompanies the textbook and scan and upload their answered pages to Blackboard for the teacher to review whether the questions were answered. Again, we are only interested in the students' doing the assigned activities for additional practice, rather than correctness of the answers since students can check their answers in the answer key that is also available on Blackboard. Finally, for students to check whether they have met the learning objectives for the unit they are working on, they have to answer a quiz provided on Blackboard. This quiz, which is automatically graded, serves as feedback for the students, and the teacher, whether students have mastered the skills presented in each unit.

\section{BLACKBOARD}

The learning management system Blackboard helps us to provide students with out-of-class activities to deepen, expand, and assess their learning. Those activities go hand in hand with in-class activities and focus on two of the four skills of language learning. Besides grammatical activities for each unit, students are provided with listening and reading activities. Another additional activity focuses on cultural aspects of the target language. Figure 2 below shows a typical set-up of activities on Blackboard, which is representative of each unit. 


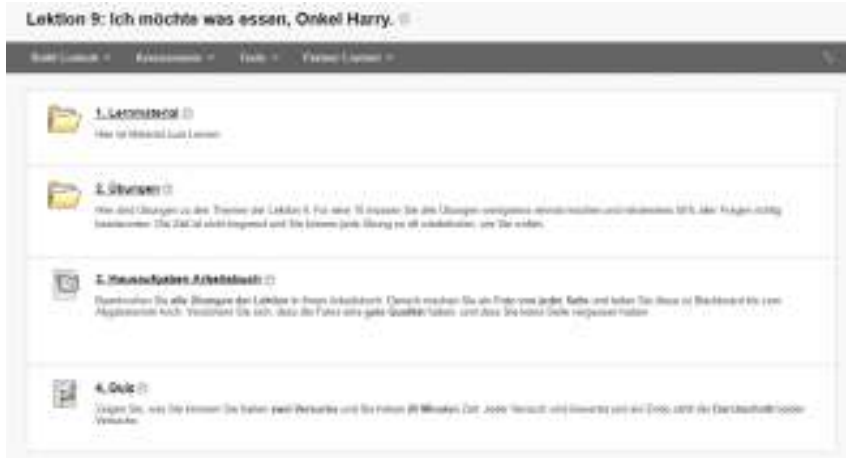

Figure 2: Screenshot of typical set-up of activities on Blackboard representative for each unit

The Blackboard activities are self-paced and obligatory, and therefore, constitute part of the students' grade. Although the activities are self-paced, there are certain restrictions: Students receive a deadline for each unit and the grade for each activity is tied to a grading rubric, which is communicated to students via the course syllabus and on Blackboard.

As shown in Figure 2 above, students are provided with two folders, a link for uploading their workbook exercises, and a quiz. In folder 1, 'Lernmaterial', students receive additional material to further their understanding of the material covered in-class. We call this folder the 'safe folder' as students can access it as often as they wish, there is no deadline, and the material in this folder is not part of any grade. Figure 3 below shows the typical content of folder 1 , representative of each unit.

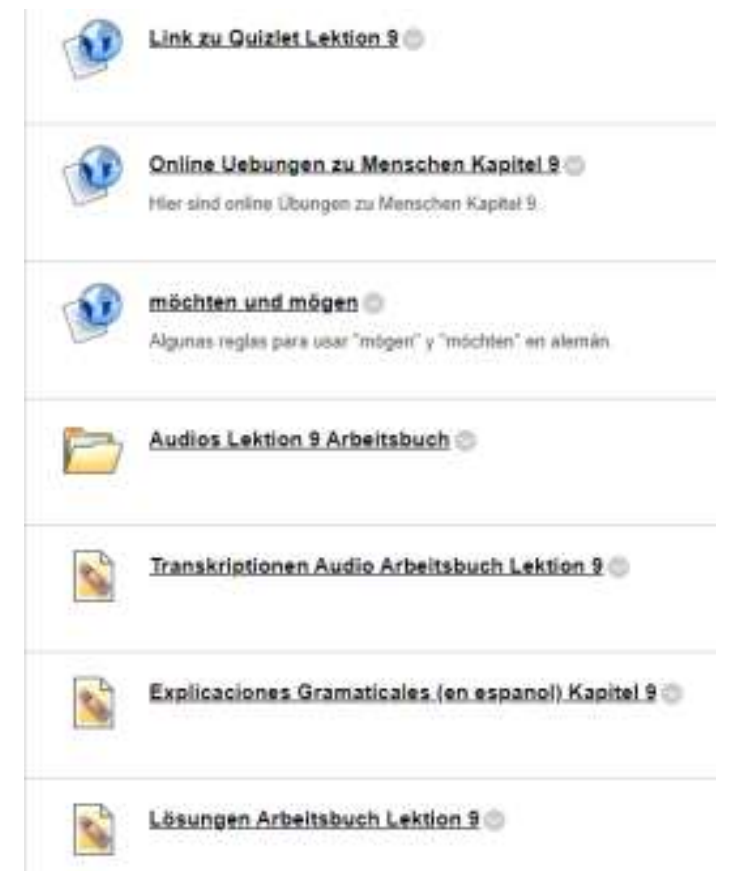

Figure 3: Screenshot of content representative of each unit in folder 1 'Lernmaterial'
The 'safe folder' contains the following activities and links to outside online sources: The vocabulary application Quizlet, which contains all vocabulary items for the specific unit and which will be introduced in a later section, a link to online activities provided by the textbook publisher, and links to other online sources that help students understand the material. Furthermore, folder 1 contains all necessary audio files and transcripts for the listening activities in the workbook. The transcripts are helpful for students whose listening skills are not yet fully developed, especially at beginner level, since they allow students to follow along while listening. The 'safe folder' also contains grammatical explanations in the students' native language as our classes are taught in $90 \%$ of the target language. Yet another document provided for our students in folder 1 is the answer key to their workbook exercises. As mentioned before, since we want our students to become autonomous learners, we decided to provide the answer key to the workbook on Blackboard. After students have done their activities in the workbook, they are encouraged to compare their answers with the provided answer key. If students then have a question or do not fully understand why their answer is wrong, we invite them to ask their teachers in the classroom or to come to our language learning center, called CAL (Centro de Aprendizaje de Lenguas), and ask for help.

The second folder, called 'Übungen' (practice activities), as seen in Figure 2 above is a graded folder and part of the students' out-of-class unit grade. It constitutes $40 \%$ of the outof-class online grade. Students can find up to seven automatically graded activities in this folder. They focus on reading, listening, grammatical structures, and cultural aspects of the target language, as can be seen in Figure 4, below. The last activity, number eight, is a link to an online application, which helps us assess the students' speaking skills. This application will be explained further below in the section entitled Flipgrid. 


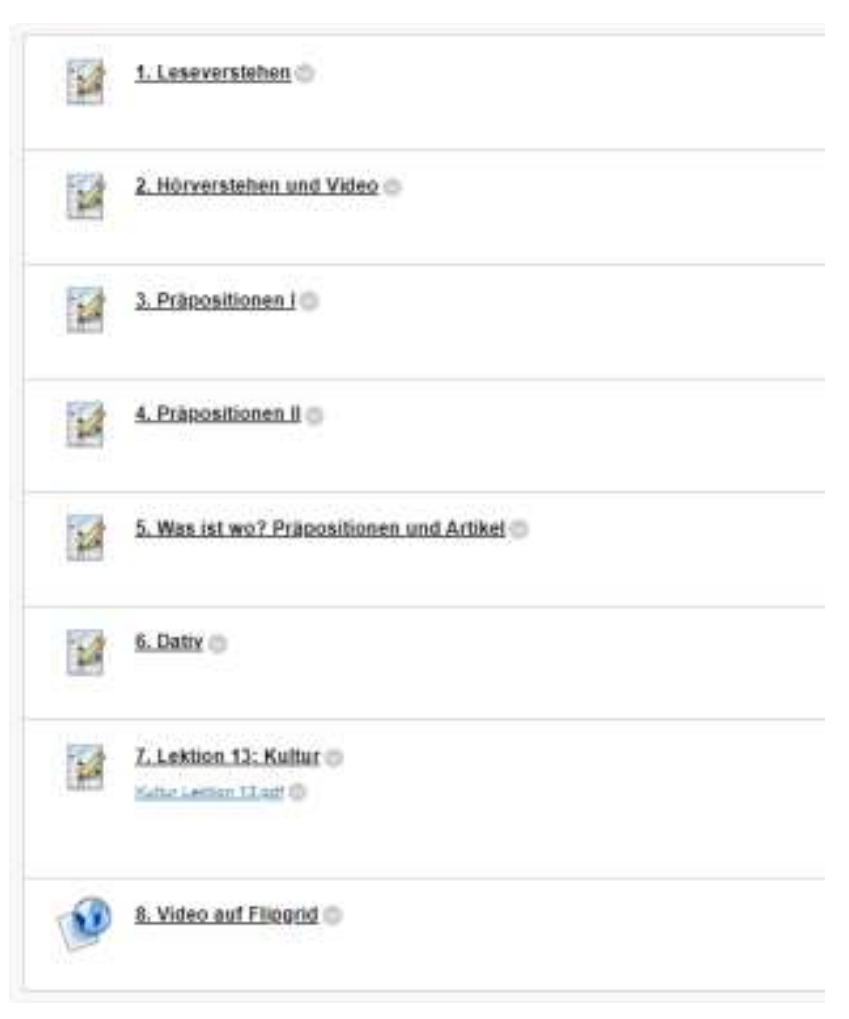

Figure 4: Screenshot of Blackboard activities representative of each unit in folder 2 'Übungen'

Students can do those eight activities as often as they wish. They do not have a time limit once the activity has been started. For each unit, students receive a deadline by which they must have completed the online activities. Although students can do the activities as often as they wish, there is one restriction: Students will only receive full credit (10 points) for all eight activities if they have reached at least half the points possible in each activity, as shown in Table 2 below. That means, students might have to do one or all activities several times to receive an average of at least half the points possible which increases the students' amount of practice of the target structures.

If students receive at least half of the possible points for each individual activity, they receive full points for the entire folder 'Übungen'. If students have done all exercises but they have not reached at least half the points possible, they will only be given 9 points for the entire folder 'Übungen'. If students have done more than half, but not all of the activities, students receive 8 points. If students have accomplished less than half of the activities, they still receive half the points possible for the folder 'Übungen'. The following table, Table 2, shows the grading rubric for the activities in folder 2, 'Übungen' in an overview, as explained above.

\begin{tabular}{|l|l|}
\hline Students finished... & Grade \\
\hline $\begin{array}{l}\text { all exercises and received at least half of } \\
\text { the possible points for each exercise. }\end{array}$ & $\begin{array}{l}10 \text { points } \\
\text { (maximum) }\end{array}$ \\
\hline $\begin{array}{l}\text { all exercises but did not receive at least } \\
\text { half of the possible points for each } \\
\text { exercise. }\end{array}$ & 9 points \\
\hline most (more than half) of the exercises. & 8 points \\
\hline some (less than half) of the exercises. & 5 points \\
\hline none of the exercises. & 0 points \\
\hline
\end{tabular}

Table 2: Grading rubric for activities in folder 2 'Übungen' for each unit

Another graded activity on Blackboard is the workbook, as can be seen in Figure 2 above, 'Hausaufgaben Arbeitsbuch'. It constitutes another $40 \%$ of the out-of-class grade. Our textbook is accompanied by a printed, hardcopy workbook. Each chapter consists of six pages of exercises such as reading, writing, listening, and grammatical structures. Before each deadline, students complete all six pages and take pictures of them. Next, students are asked to upload the pictures as a pdf file to Blackboard (we made this decision so students can continue to work with the book while we grade the homework rather than asking students to turn in their books).

As mentioned above, folder 1, 'Lernmaterial', contains the answer key to the workbook exercises. Consequently, teachers do not check for correctness but for the punctual submission and completeness of the exercises. Table 3, below, shows the grading rubric for the workbook activities.

\begin{tabular}{|l|l|}
\hline Number of exercises accomplished & Grade \\
\hline $\begin{array}{l}\text { All exercises were done and submitted on } \\
\text { time. }\end{array}$ & $\begin{array}{l}10 \text { points } \\
\text { (maximum) }\end{array}$ \\
\hline $\begin{array}{l}\text { More than half, but not all, exercises were } \\
\text { done and submitted on time. }\end{array}$ & 8 points \\
\hline $\begin{array}{l}\text { Some exercises, but less than half, were } \\
\text { done and submitted on time. }\end{array}$ & 5 points \\
\hline $\begin{array}{l}\text { None of the exercises were done or they } \\
\text { were submitted late. }\end{array}$ & 0 points \\
\hline
\end{tabular}

Table 3: Grading rubric for workbook activities for each unit

The final activity on Blackboard is the 'Quiz', which is number four in Figure 2. It constitutes $20 \%$ of the out-of-class grade. Here, learners must answer 20 questions that are similar to some of the eight activities in 'Übungen'. The quiz assesses our students' grammatical and vocabulary knowledge. Students have 20 minutes to answer all the questions and they can take the quiz up to two times. If they decide to take the quiz twice, the system calculates the average of those two tries. If students are satisfied with their grade on the first try, they do not have to take the quiz again. The following table, Table 4, shows the grading rubric for the quiz. 


\begin{tabular}{|l|l|}
\hline Points reached on the quiz & Grade \\
\hline 20 (maximum) - 19 & 10 (maximum) \\
\hline $18-17$ & 9.5 \\
\hline $16-15$ & 9.0 \\
\hline $14-13$ & 8.5 \\
\hline $12-11$ & 8.0 \\
\hline 10 & 7.0 \\
\hline 9 & 6.0 \\
\hline 8 & 5.0 \\
\hline 7 & 4.0 \\
\hline 6 & 3.0 \\
\hline 5 & 2.0 \\
\hline $4-2$ & 1 \\
\hline $1-0$ & 0 \\
\hline
\end{tabular}

Table 4: Grading rubric for the Quiz for each unit

However, Blackboard is only one of the tools we have implemented in order to provide our students with additional online practice of the material covered in class. In the following sections, we will outline how we are including additional online components. It is important to mention that all of these online activities have been designed for each specific unit and bearing in mind the students' needs, as well as a number of quality criteria, presented in the challenges section below.

\section{FLIPGRID}

Flipgrid, a social learning video platform, is an application that enables learners to create and share recordings with classmates and the teacher. The teacher is responsible for creating a 'grid', that is to say, an online meeting place and a question or task to be addressed, and learners then record a response, using their cell phones, tablets or computer to share with class mates. Its main tool comprises videos that can be uploaded and shared for educational purposes. The application is available as a desktop version and as a smartphone application. We integrated Flipgrid as one online component to assess our students`speaking skills. Our students are asked to create a one to two minutes video for every unit. The prompt for each unit video and the link to each video folder, called grid, is shared via Blackboard, as shown in Figure 4 number eight. Our students have to respond to a video created by the teacher in which the teacher or another person provides an incentive for the students to respond via video. In that way, students respond to a real person and are engaged in an asynchronous yet authentic task. Students can also respond to each other via video, which fosters the communicative and social component of our students' language learning experience. Flipgrid enables us to provide our students with communicative learning opportunities and fosters communicative language teaching and learning overall.

Figure 5 below shows folders, or so-called grids, that have been established for each level of our German classes on Flipgrid.

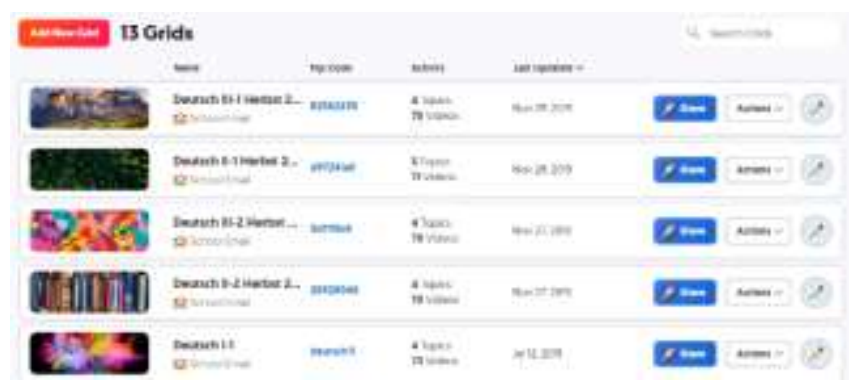

Figure 5: Screenshot of Flipgrid's grid folders for German

Within each folder, or grid, teachers can create so-called topics, as shown in Figure 6 below. In that way, teachers can comfortably collect all students' videos for one unit in one Flipgrid topic.

The grade for the speaking activity on Flipgrid is part of the 'Übungen' grade. The speaking activity assesses whether students answered the prompt fully and correctly. It also assesses the students' comprehensibility, which for us also contemplates pronunciation and fluency.

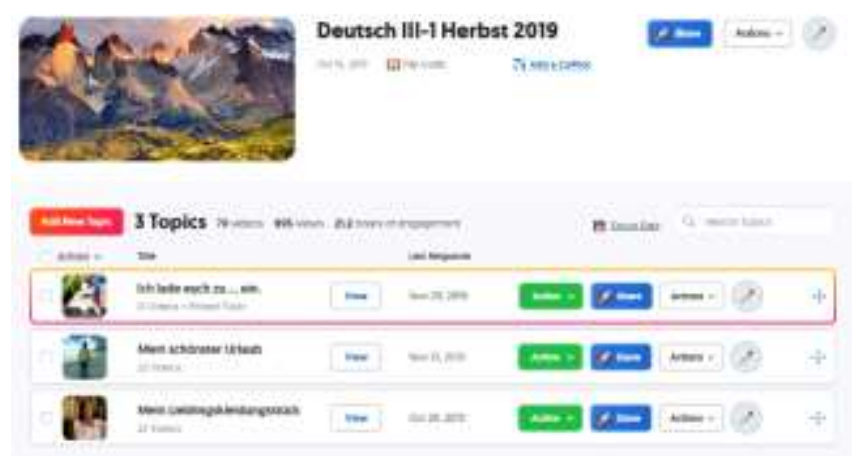

Figure 6: Screenshot of topics within one grid on Flipgrid

We do not assess grammatical correctness since we want to encourage our students to use the target language freely without having to worry about grammar (which, in our experience, may inhibit especially beginners when trying to use the foreign language). Students can see their grade and our feedback on Blackboard and within the application, as can be seen in Figure 7 below. 


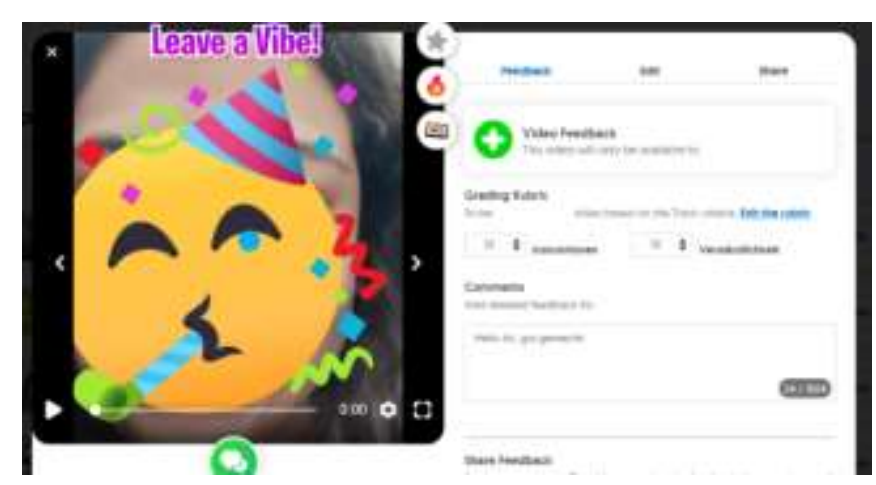

Figure7: Screenshot of video, teacher comment, and grading rubric on Flipgrid

The grading rubric on Flipgrid is customizable. Additionally, teachers have the possibility of sending students short feedback or comments via e-mail, as shown in Figure 7 above. Students of the same class can see each other's videos, leave a comment, and respond by video or by using emojis and socalled stickers encouraging student-to-student interaction.

\section{ADDITIONAL OUT-OF-CLASS ACTIVITIES}

In addition to our graded out-of-class activities, we offer additional, non-graded activities online. Social media applications such as Instagram, Facebook, YouTube, Pinterest, and language learning applications such as Quizlet and Duolingo Classroom help us engage our learners with the target language outside the classroom.

\section{INSTAGRAM AND FACEBOOK}

We use the social media application Instagram to share interesting language facts, information about the target language, and news about the target language countries. Additionally, we use Instagram's features called 'Highlights' and 'Stories' to ask questions or make comments in the target language, which students can respond to. Besides Instagram, we also use the social media application Facebook. Facebook helps us share memes in or related to the target language, videos, news, and other relevant information about the target language or culture. By using those two applications and providing our students with engaging material in or about the target language, we encourage our students to stay engaged with the target language outside the classroom as much as possible which is vital in a foreign language context.

Figure 8 below, for example, shows a post of a picture that was taken during one of our German classes which was subsequently shared on Instagram. Students were invited to comment on the picture using the target language.

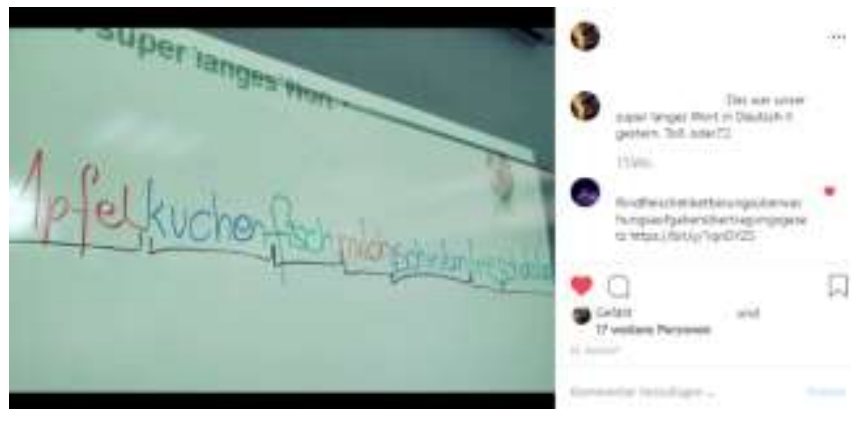

Figure 8: Screenshot of an Instagram post

\section{YOUTUBE}

In addition, we implemented the video sharing service YouTube for various reasons. For example, we provide our students with music in the target language. Students can follow our channel and receive news and updates if something has been added to the channel. YouTube allows us to collect instructional videos and authentic material from other users, and to upload our own instructional videos all in one place. Links to YouTube can be easily shared with our students via e-mail or via Blackboard. In our experience, students enjoy watching the authentic materials provided on YouTube, which increases their motivation to engage with the target language outside the classroom. Applying Keller's (1987) ARCS model, which stands for attention, relevance, confidence, and satisfaction, four salient factors to become and stay motivated as a learner, we try to foster the motivational component of our language learners through authentic, interesting, relevant, and age-appropriate videos on YouTube. By using YouTube, we also try to appeal to our learners' affective and social language learning component and motivate them to be engaged with and curious about the target language through the use of authentic material.

\section{PINTEREST}

Pinterest is yet another application that we integrated as part of our out-of-class offer. The platforms' main purpose is the collection of photos and images and sharing them with other users. It allows its users to create folders and to collect online images within those folders. Figure 9 below shows three folders on Pinterest for our German beginner courses. 


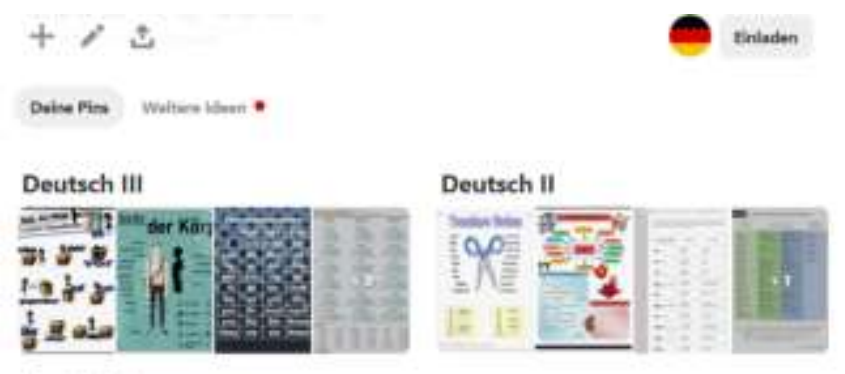

Deutsch I

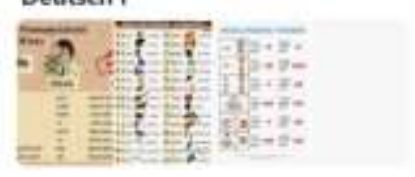

Figure 9: Screenshot of folders with images on Pinterest

We are using Pinterest to share images, tables, grammar tips, and infographics related to specific grammatical topics or vocabulary items in the target language to appeal to our visual learners. We also created folders for every class level with a collection of images, tables, and infographics about grammar topics, and vocabulary taught in that specific level.

\section{QUIZLET AND DUOLINGO CLASSROOM}

Quizlet is an application that allows users to learn and practice vocabulary. Vocabulary items can either be learned in regular flashcard mode or students can choose to practice via game mode. Quizlet allows teachers to create virtual classes, folders, and so-called vocabulary sets within those folders and classes. We encourage our students to learn the vocabulary using this application as it can be used on the smartphone and it might be more engaging to some students through its game mode. Another advantage of this application is that it reads the vocabulary items to its users. In that way, students can learn the meaning and pronunciation of a vocabulary item at the same time. Figure 10 below shows classes for our beginner courses on the left-hand side and folders with vocabulary sets for each unit on the right-hand side.

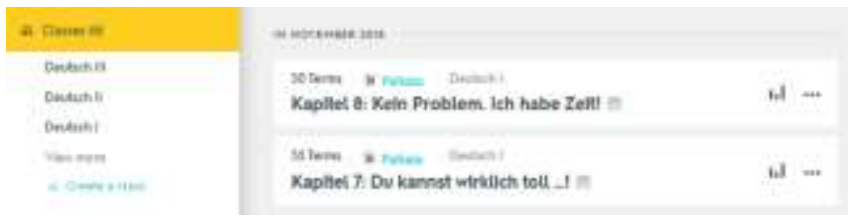

Figure 10: Screenshot of classes (Deutsch I, II, and III), folders, and vocabulary sets on Quizlet

Duolingo classroom is an additional offer provided by the language learning application Duolingo. Whereas Duolingo is used by individual learners, Duolingo Classroom can be used for language learning groups and classes. Duolingo Classroom allows us to create virtual classrooms and to assign activities to students who are part of the virtual classroom. Figure 11 below shows an assignment in the virtual classroom.

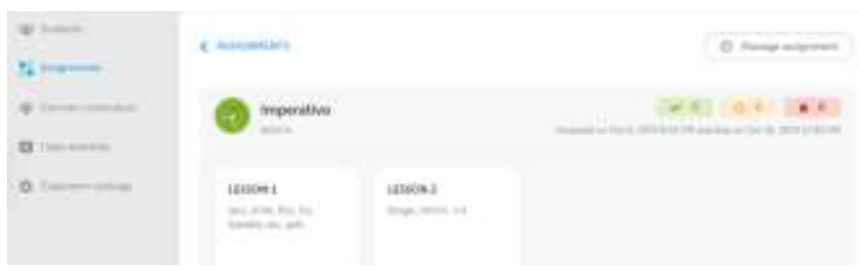

Figure 11: Screenshot of an assignment in the virtual classroom in Duolingo classroom

The application offers different grammatical topics to be studied and teachers can assign a specific grammatical topic that is taught in class. This provides students with yet another means to practice the target language outside the classroom. The language learning application offers extensive activities and material for practicing spelling and listening comprehension. The exercises follow a certain system that conveys content from level to level in a more playful and engaging way. In addition, the language learning application is adaptive to the language learner and customizes its content for each individual learner. For example, if a student has problems with sentence structure or has trouble remembering a vocabulary item, the structure and the item will be repeated more often in spaced repetitions. In that way, learners receive more opportunitites to practice the less familiar structures or vocabulary items. Through the use of varied activities, we have found that students are more engaged with the target language, which is evidenced in the students' positive comments on the teacher evaluation forms. If students furthermore decide to sign up for the virtual classroom on Duolingo, which has to be previously created by the teacher, they will receive notifications via e-mail when an activity has been assigned.

As the examples outlined above clearly demonstrate, technology can be successfully integrated into the foreign language classroom. However, this implemention has not been without challenges. In what follows, we will briefly outline three specific challenges we faced during our implementation process and discuss how we have met them.

\section{CHALLENGES}

Challenge one: Increased technological sophistication is not automatically correlated with increased pedagogical effectiveness. As we were contemplating how to integrate technology in our foreign language classes, we had to carry out 
the following four actions, if we wanted these tools to contribute sucessfully to our students' learning:

1. identify which technologies are needed to support [our] curricular goals and objectives;

2. specify how the tools will be used to help [our] students meet and demonstrate these goals;

3. select and use appropriate technologies to address needs, solve problems, and resolve issues related to [our] own professional practice and growth; and

4. enable [our] students to use appropriate technologies in all phases of the learning process including exploration, analysis, and production. (Cennamo, Ross, \& Ertmer, 2010, p. 10, emphasis in the original)

Considering that our foreign language classes follow the communicative language teaching philosophy, we had to assure that our classes help students achieve competency in the four skills while also developing fluency. Being aware of the fact that the tools we chose needed to be available and free of cost to our faculty and students alike while also being «guided by a particular theoretical model»(Blake, 2008, p. 3), we decided to adopt the interaction model believing that it is through the meaningful interaction with other language learners as well as the target language that learning will take place (see Chapelle, 2001). However, since the learners' interaction with the target language is limited, as pointed out above, we decided to create additional opportunities for interaction outside the classroom through the use of carefully selected technological tools and activities with the aim of engaging our students further with the target language outside the classroom.

Challenge two: determination of the attributes of our technological tools that can be profitably exploited for pedagogical purposes. One specific concern for us was to provide students with additional practice outside the classroom while also providing individual feedback (this, particularly, has been a challenge considerning the number of students in each class). Tools such as Blackboard are an efficient way to further engage students with the target language while the automated grading procedure allows for immediate and (if set up) individual feedback concerning the learners' performance. Although representative of the early stage of technology as drill masters (Blake, 2008), this use of the online component allows for frequent, self-paced repetition of the target forms, suggested by Chapelle (2003) as one way to render input salient, and thus further supporting learning. It also provides efficient focus on form, which, we believe, is coming up short very often in the communicative classroom which tends to focus on meaning only.

Another important aspect for us was to provide additional opportunities to practice the oral skills. As mentioned previously, the number of students in each class makes it difficult to provide opportune and personalized feedback. Tools such as Flipgrid, YouTube or the Duolingo Classroom allow students to practice both their listening and speaking skills while recordings of their oral production provides us with a record of the students' language use that can be assessed at our own convenience. In addition, technology can be used as a medium for communcation fostering interpersonal interaction which potentially prompts attention to both language form and meaning (Chapelle, 2003) while also providing authentic materials which are not only of current interest to the students but which can also form the basis for more engaging learning activities (Motteram, 2011), thus increasing learner motivation.

Challenge three: Assessment of the pedagogical effectiveness of our out-of-class activities. As mentioned above, we opted for an equal weight of the in-class and online components. However, we still had to decide which types of online activities to include in order to assure that they are, in fact, effective but also practical. We based our decisions on Chapelle's criteria to assess the pedagogical effectiveness of CALL (Computer Assisted Language Learning) activities (2001, p. 55), represented in Table 5 below. We would like to point out, however, that even though CALL in its earliest sense may no longer represent the latest theory and practice concerning the use of technology in the language classroom, we consider a CALL activity any type of language learning activity that involves the use of technology, be it using a computer, a tablet, or even a smart phone. We strongly believe that the evaluation criteria put forth by Chapelle continue to be relevant in today's varied learning environments and teachers who wish to implement technology in their language classrooms are strongly advised to consider the criteria summarized in Table 5 as they plan and structure their additional, technology supported learning activities.

In accordance with Chapelle (2001), the most important criterion for the selection of any CALL task is its potential for language learning to take place. While focus on meaning is important, since the learning outcome of all our language classes is communicative competence, which encompasses grammatical (or linguistic) competence, sociolinguistic competence (the sociocultural, pragmatic, and discourse rules present in a particular culture), as well as strategic competence (the verbal and non-verbal compensatory communication skills) (Canale \& Swain, 1980), beneficial focus on form has been somewhat neglected in the communicative classroom potentially leading to problems with grammatical correctness in the future.

\begin{tabular}{|l|l|}
\hline $\begin{array}{l}\text { Language learning } \\
\text { potential }\end{array}$ & $\begin{array}{l}\text { The degree of opportunity present } \\
\text { for beneficial focus on form. }\end{array}$ \\
\hline Learner fit & $\begin{array}{l}\text { The amount of opportunity for } \\
\text { engagemeent with language under }\end{array}$ \\
\hline
\end{tabular}




\begin{tabular}{|l|l|}
\hline & $\begin{array}{l}\text { appropriate conditions given } \\
\text { learner characteristics. }\end{array}$ \\
\hline Meaning focus & $\begin{array}{l}\text { The extent to which learners' } \\
\text { attention is directed toward the } \\
\text { meaning of the language. }\end{array}$ \\
\hline Authenticity & $\begin{array}{l}\text { The degree of correspondence } \\
\text { between the CALL activity and } \\
\text { target language activities of interest } \\
\text { to learners out of the classroom. }\end{array}$ \\
\hline Positive impact & $\begin{array}{l}\text { The positive effects of the CALL } \\
\text { activity on those who participate in } \\
\text { it. }\end{array}$ \\
\hline Practicality & $\begin{array}{l}\text { The adequacy of resources to } \\
\text { support the use of the CALL } \\
\text { activity. }\end{array}$ \\
\hline
\end{tabular}

Table 5: Pedagogical effectiveness of CALL activities

Second, the CALL activity needs to be able to engage the learners. This will depend on the language learning context, the students' motivation for learning the language, as well as the students' background. If the CALL activity is authentic, meaning the students can relate to why they have to perform the activity in the first place, focuses equally on form and meaning, and fits the learners' needs, it will create a positive impact on the students which positively affects the learning process.

Finally, practicality also needs to be considered. We must make sure that the online activities do not, in fact, result in a greater time investment than conventional learning tasks when being reviewed by the teacher or require additional tools or technical support beyond the means of the students and the institution.

\section{CONCLUSIONS}

The overarching purpose of our article is to share how we have implemented hybrid learning in our foreign language classes. As our discussion shows, there are many different tools available to today's teachers that can help engage students outside the classroom. However, it is of utmost importance that teachers understand that on the one hand, technology is not monolithic, i.e., there is a great variety of different tools available, and that the use of technology, on the other hand, does not constitute a methodology in and of itself. Rather, before implementing online activities, teachers are advised to carefully assess not only the tools they are considering to implement but also the pedagogical effectiveness of the activities students are supposed to complete outside the classroom. Not all CALL activities are automatically and equally effective and hybrid learning, per se, does not assure language learning success. Rather, each online activity needs to be carefully evaluated and adjustments need to be made whenever the need arises. While being faced with a number of challenges during our implementation process of hybrid learning, we learned not only to be flexible regarding the tools we wanted to implement but also to continually reflect on the pedagogical effectiveness and assessment criteria of our online activities to ensure that they continue to support our students' language learning process. As a next step, a more formal enquiry into our students' perception regarding the helpfulness of the online component and how we can continue to improve it is in order.

\section{LINKS TO APPLICATIONS PRESENTED}

[1] http://www.blackboard.com

[2] http://www.flipgrid.com

[3] http://www.instagram.com

[4] http://www.facebook.com

[5] http://www.youtube.com

[6] http://www.pinterest.com

[7] http://www.quizlet.com

[8] http://www.schools.duolingo.com

\section{REFERENCES}

[1] Blake, R. (2008). Brave new digital classroom: Technology and foreign language learning. Washington, DC: Georgetown University Press.

[2] Canale, M., \& Swain, M. (1980). Theoretical bases of communicative approaches to second language teaching and testing. Applied Linguistics; 1(1): $1-47$

[3] Cennamo, K., Ross, J., \& Ertmer, P. (2010). Technology integration for meaningful classroom use: A standards-based approach. Belmont, CA: Wadsworth.

[4] Chapelle, C. (2001). Computer applications in second language acquisition. Cambridge, UK: Cambridge University Press.

[5] Chapelle, C. (2003). English language learning and technology. Philadelphia, PA: John Benjamins.

[6] Halverson, L.R., \& Graham, C.R. (2019). Learner engagement in blended learning environments: A conceptual framework. Online Learning; 23(2): 145-178. doi:10.24059/olj.v23i2.1481

[7] Keller, J.M. (1987). Development and use of the ARCS model of instructional design. Journal of Instructional Development; 10(3): 2-10.

[8] Knight, B. (2018). How long does it take to learn a foreign language? [Blog post]. Retrieved from: https://www.cambridge.org/elt/blog/wpcontent/uploads/2018/10/How-long-does-it-take-to-learn-a-foreignlanguage.pdf

[9] Motteram, G. (2011). Developing language-learning materials with technology. In B. Tomlinson (Ed.). Materials development in language teaching (pp. 303-327). Cambridge, UK: Cambridge University Press.

[10] Park, Martin, \& Lambert. (2019). Examining predictive factors for student success in a hybrid learning course. The Quarterly Review of Distance Education; 20(2): 11-27.

[11] Wang, Huang, Schunn, Zou, \& Ai. (2019). Redesigning flipped classrooms: A learning model and its effects on student perceptions. Higher Education; 78: 711-728. doi:10.1007/s10734-019-00366-8 